\title{
PENGARUH BUDAYA ORGANISASI DAN KOMITMEN TERHADAP KINERJA GURU PADA SMK GKPS 2 PEMATANGSIANTAR
}

\author{
Oleh: \\ Sofi Chrisdayanti Purba \\ S1 Manajemen \\ Darwin Lie, Efendi, Andy Wijaya
}

Abstraksi

Adapun rumusan masalah penelitian ini adalah bagaimana pengaruh Budaya Organisasi dan Komitmen terhadap Kinerja Guru Pada SMK GKPS 2 Pematangsiantar. Penelitian ini menggunakan desain penelitian kepustakaan dan penelitian lapangan. Populasi pada penelitian ini adalah guru SMK GKPS 2 Pematangsiantar berjumlah 64 guru. Data yang digunakan adalah data dengan cara kualitatif dan data kuatitatif, dan teknik pengumpulan data dengan cara kuesioner, wawancara dan dokumentasi. Kemudian teknik analisa data menggunakan metode deskriptif kualitatif dan metode deskriptif kuantitatif.

Hasil analisis dari regresi linier berganda yaitu $\hat{Y}=68,710+0,715 X_{1}+0,914 X_{2}$ artinya budaya organisasi dan komitmen berpengaruh positif terhadap kinerja guru. Hubungan ketiga variabel adalah kuat yaitu $r=0,672$. Dari koefisien determinasi dapat dijelaskan tinggi rendahnya kinerja guru sebesar $45,2 \%$ dan sisanya $54,8 \%$ dijelaskan oleh faktor lainnya yang yang tidak dibahas dalam penelitian ini. Dari hasil pengolahan dan perhitungan kuesioner, penulis mendapatkan kesimpulan bahwa budaya organisasi dan komitmen yang diterapkan SMK GKPS 2 Pematangsiantar berpengaruh positif dan signifikan terhadap kinerja guru. Hal ini dibuktikan melalui uji hipotesis secara simultan, dimana hasil uji $\mathrm{f}_{\text {hitung }}(25,170)>\mathrm{f}_{\text {tabel }}(3,15)$ dengan taraf signifikansi $0,000<$ alpha 0,05 .

Kata Kunci: Budaya Organisasi, Komitmen dan Kinerja Guru

\section{Abstraction}

The formulation of this research problem is how the influence of Cultural Organization and Commitment to the Teacher Performance at SMK GKPS 2 Pematangsiantar. The research method used in this paper is literature research and field research. Its population is employees of SMK GKPS 2 Pematangsiantar amounted to 64 people. The data used are data by qualitative and qualitative data, and data collection techniques by questionnaire, interview and documentation. Then the technique of data analysis using qualitative descriptive method and quantitative descriptive method.

Results of analysis of multiple linear regression is $\hat{\mathrm{Y}}=68,710+0,715 \mathrm{X}_{1}+0,914 \mathrm{X}_{2}$ means there is a positive influence between cultural organization and commitment on teacher performance. The strength of the relationship between the three variables is strong, is $r=0,672$. From the coefficient of determination can be explained high low employee performance 45,2\% and the remaining 54,8\% explained by other factors that are not discussed in this study. From the results of processing and calculation of the questionnaire, the authors get the conclusion that the cultural organization and commitment applied SMK GKPS 2 Pematangsiantar have a positive and significant effect on teacher performance. This is proven by hypothesis testing simultaneously, where the test result f $f_{\text {hitung }}(25,170)>f_{\text {hitung }}(3,15)$ with significance level $0,000<$ alpha 0,05 .

\section{Keywords: Cultural Organization, Commitment and Teacher Performance}

\section{A. PENDAHULUAN}

\section{Latar Belakang Masalah}

Sumber daya manusia merupakan hal yang sangat penting dan harus dimiliki dalam upaya pencapaian tujuan organisasi. Sumber daya manusia adalah individu proaktif yang bekerja sebagai penggerak suatu organisasi, baik itu di dalam institusi maupun perusahaan yang memiliki fungsi sebagai aset sehingga harus dilatih dan dikembangkan kemampuannya. Dalam dunia pendidikan, asset yang harus dilatih dan dikembangkan ialah kinerja guru. Kinerja guru yang optimal dan berkualitas, akan melahirkan peserta didik yang berkualitas.

Sekolah Menengah Kejuruan Gereja Kristen

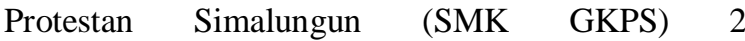
Pematangsiantar merupakan instansi yang bergerak pada bidang pendidikan tehnik (kejuruan). Sekolah tehnik ini bertujuan untuk untuk meningkatkan sumber daya manusia yang berkualitas serta memiliki daya saing tinggi. SMK GKPS 2 Pematangsiantar ingin menciptakan sumber daya manusia yang memiliki keahlian yang mampu bersaing atau berkompetisi di dalam maupun di luar negeri, tujuan tersebut dituangkan dalam visi dan misi organisasi, dan untuk memenuhi tujuan tersebut maka dibutuhkan kinerja guru yang optimal serta berkualitas pula.

Kinerja guru menurut Peraturan Menteri Pendidikan Nasional Nomor 16 Tahun 2007 tentang Standar Kualifikasi Akademik dan Kompetensi Guru, memiliki 14 dimensi pengukuran kinerja yang bersumber dari kompetensi guru.

Budaya organisasi yang diterapkan dalam SMK GKPS 2 Pematangsiantar adalah 7 budaya malu dengan dimensi, malu karena datang terlambat 
dilihat dari ketepatan waktu guru tiba/ datang ke sekolah, malu karena melihat rekan sibuk melakukan aktivitas dilihat dari sikap kerja sama, toleransi serta sikap memotivasi antar sesama guru, malu karena melanggar peraturan dilihat dari sikap guru dalam menerapkan budaya tata tertib di sekolah, malu untuk berbuat salah dilihat dari ketelitian, konsentrasi, serta kesempurnaan guru dalam menyelesaikan pekerjaan, malu karena bekerja tidak berprestasi dilihat dari ketekunan bekerja serta kreativitas guru dalam bekerja, malu karena tugas tidak terlaksana atau sesuai tidak tepat waktu dilihat dari ketepatan waktu guru dalam menyelesaikan pekerjaannya serta kualitas kerja yang dihasilkan, dan malu karena tidak berperan aktif dalam mewujudkan $7 \mathrm{~K}$ dilihat dari peran serta kesadaran guru dalam mewujudkan lingkungan sekolah yang nyaman dan aman.

Selain budaya organisasi, kinerja guru juga dapat dipengaruhi oleh komitmen. Adapun dimensi komitmen pada SMK GKPS 2 Pematangsiantar yaitu komitmen afektif, komitmen berkelanjutan, dan komitmen normatif.

\section{Rumusan Masalah}

a. Bagaimana gambaran budaya organisasi, komitmen, dan kinerja guru pada SMK GKPS 2 Pematangsiantar.

b. Bagaimana pengaruh budaya organisasi dan komitmen terhadap kinerja guru pada SMK GKPS 2 Pematangsiantar baik secara simultan maupun parsial.

\section{Tujuan Penelitian}

a. Untuk mengetahui gambaran budaya organisasi, komitmen, dan kinerja guru pada SMK GKPS 2 Pematangsiantar.

b. Untuk mengetahui pengaruh budaya organisasi dan komitmen terhadap kinerja guru pada SMK GKPS 2 Pematangsiantar baik secara simultan maupun parsial.

\section{Metode Penelitian}

Lokasi atau tempat penelitian ini dilakukan di SMK GKPS 2 Pematangsiantar yang berada di Jalan Merek Raya Pematangsiantar. Pada penelitian ini yang menjadi populasi adalah guru SMK GKPS 2 Pematangsiantar sebanyak 64 orang. Seluruh guru yang berjumlah 64 orang akan menjadi sampel sebagai responden untuk menjawab kuesioner yang penulis sebarkan, mengingat jumlahnya kurang dari 100 (seratus) orang dan ketersediaan waktu penulis serta untuk keakuratan hasil penelitian.

Adapun desain penelitian yang digunakan dalam penulisan skripsi ini adalah Penelitian Kepustakaan (Library Research) dan Penelitian Lapangan (Field Research). Teknik pengumpulan data yang dilakukan penulis dalam penelitian ini adalah berupa Kuesioner, Wawancara dan Dokumentasi. Adapun jenis data yang digunakan dalam penelitian ini adalah jenis data kualitatif dan data kuantitatif. Hasil data yang diperoleh dari lapangan akan dianalisis secara deskriptif baik bersifat kualitatif dan kuantitatif.

\section{B. LANDASAN TEORI}

1. Manajemen dan Manajemen Sumber Daya Manusia

Menurut Daft (2002:8), manajemen adalah pencapaian tujuan organisasi dengan cara yang efektif melalui perencanaan, pengorganisasian, pengarahan dan pengendalian sumber daya organisasi. Menurut Griffin (2004:8), manajemen merupakan suatu rangkaian aktivitas (termasuk perencanaan dan pengambilan keputusan, pengorganisasian, kepemimpinan, dan pengendalian). Sedangkan menurut Robbins dan Mary (2011:7), manajemen adalah hal yang dilakukan manajer melibatkan aktivitas-aktivitas koordinasi dan pengawasan terhadap pekerjaan orang lain, sehingga pekerjaan tersebut dapat diselesaikan secara efisien dan efektif.

Menurut Mondy (2008:4), manajemen sumber daya manusia adalah pemanfaatan sejumlah individu untuk mencapai tujuan organisasi. Sedangkan Menurut Bangun (2012:6), manajemen sumber daya manusia adalah suatu proses perencanaan, pengorganisasian, penyusunan staf, pengendalian dan pengawasan terhadap pengadaan, pengembangan, pemberian kompensasi, pengintegrasian, pemeliharaan dan pemisahan tenaga kerja untuk mencapai tujuan organisasi. Menurut Mathis dan John (2006:3), manajemen sumber daya manusia adalah rancangan sistem-sistem formal dalam sebuah organisasi untuk memastikan penggunaan bakat manusia secara efektif dan efisien guna mencapai tujuan-tujuan organisasional.

Menurut Mondy (2008:4), fungsi-fungsi manajemen sumber daya manusia adalah sebagai berikut:

a. Penyediaan Staf (Staffing)

Penyediaan Staf merupakan proses yang menjamin suatu organisasi untuk selalu memiliki jumlah karyawan yang tepat sesuai dengan keahlian-keahlian yang memadai dalam pekerjaan dan waktu yang tepat untuk mencapai tujuan organisasi.

b. Kompensasi

Kompensasi yaitu semua yang mencakup imbalan total yang diberikan kepada karyawan sebagai timbal balik untuk jasa mereka.

c. Pengembangan Sumber Daya Manusia

Pengembangan Sumber Daya Manusia adalah fungsi manajemen sumber daya manusia yang tidak hanya terdiri dari pelatihan dan pengembangan namun juga aktivitas-aktivitas perencanaan dan pengembangan karir individu, pengembangan organisasi dan penilaian kinerja.

d. Hubungan Karyawan dan Buruh

Dalam sebuah organisasi, serikat pekerja mewakili keinginan para karyawan perusahaan.Aktivitas sumber daya manusia disebut sebagai hubungan industrial untuk melakukan perlindungan kolektif.

e. Keselamatan dan Kesehatan 
Keselamatan adalah perlindungan bagi karyawan dari luka-luka yang disebabkan kecelakaan yang terkait dengan pekerjaan.Kesehatan adalah bebasnya karyawan dari sakit secara fisik maupun emosi.

\section{Budaya Organisasi}

Menurut Sutrisno (2010:2), budaya organisasi dapat didefinisikan sebagai perangkat sistem nilai-nilai (values), keyakinan-keyakinan (beliefs), asumsi-asumsi (assumptions), atau normanorma yang telah lama berlaku, disepakati dan diikuti oleh para anggota suatu organisasi sebagai pedoman perilaku dan pemecahan masalah-masalah organisasinya. Menurut Robbins (2002:279), budaya organisasi merujuk kepada suatu sistem pengertian bersama yang dipegang oleh anggota-anggota suatu organisasi, yang membedakan organisasi tersebut dari organisasi lainnya. Menurut Kreitner dan Angelo (2015:62), budaya organisasi (organizational culture) adalah perangkat asumsi yang dibagi dan diterima secara implisit begitu saja serta dipegang oleh satu kelompok yang menentukan bagaimana hal itu dirasakan, dipikirkan, dan bereaksi terhadap lingkungan yang beragam.

Menurut Peraturan yang diterapkan oleh SMK GKPS 2 Pematangsiantar tentang budaya organisasi, terdapat 7 jenis budaya malu, yaitu:

a. Malu karena datang terlambat.

b. Malu karena melihat rekan sibuk melakukan aktivitas.

c. Malu karena melanggar peraturan.

d. Malu untuk berbuat salah.

e. Malu karena bekerja tidak berprestasi.

f. Malu karena tugas tidak terlaksana atau sesuai tidak tepat waktu.

g. Malu karena tidak berperan aktif dalam mewujudkan $7 \mathrm{~K}$

\section{Komitmen}

Menurut Robbins (2007:140), komitmen adalah suatu organisasi tertentu dan tujuannya serta berniat memelihara keanggotaannya dalam organisasi itu. Sutrisno (2010:296), menyatakan bahwa komitmen merupakan sikap loyalitas pekerja terhadap organisasinya dan juga merupakan suatu proses mengekspresikan perhatian dan partisipasinya terhadap organisasi. Menurut Luthans dalam Sutrisno (2010:292), komitmen organisasi merupakan keinginan yang kuat untuk menjadi anggota dalam suatu kelompok, kemauan usaha yang tinggi untuk organisasi, dan suatu keyakinan tertentu dan penerimaan terhadap nilai-nilai dan tujuantujuan organisasi.

Robbins dan Timothy (2008:101), membedakan komitmen organisasional atas tiga indikator, yaitu :

a. Komitmen afektif (Affective Commitment), perasaan emosional untuk organisasi dan keyakinan dalam nilai-nilainya.

b. Komitmen berkelanjutan (Continuance Commitment), nilai ekonomi yang dirasa dari bertahan dalam suatu organisasi bila dibandingkan dengan meninggalkan organisasi tersebut.

c. Komitmen normatif (Normative Commitment), kewajiban untuk bertahan dalam organisasi untuk alasan-alasan moral atau etis.

\section{Kinerja Guru}

Lawler dan Porter dalam Sutrisno (2010:170), mengemukakan kinerja adalah kesuksesan seseorang dalam melaksanakan tugas. Menurut Mathis dan John (2006:113), kinerja adalah suatu hasil kerja yang dicapai seseorang dalam melaksanakan tugastugas yang dibebankan kepadanya yang disarankan atas pengalaman, kesungguhan, dan kecakapan serta waktu. Menurut Mangkunegara (2017:67), kinerja merupakan hasil kerja secara kualitas dan kuantitas yang dicapai oleh seorang pegawai dalam melaksanakan tugasnya sesuai dengan tanggung jawab yang diberikan kepadanya.

Menurut Peraturan Menteri Pendidikan Nasional Nomor 16 Tahun 2007 tentang Standar Kualifikasi Akademik dan Kompetensi Guru, terdapat 14 indikator pengukuran kinerja guru yang bersumber dari kompetensi guru, yaitu sebagai berikut :

a. Menguasai karakteristik peserta didik.

Guru mencatat dan menggunakan informasi tentang karakteristik peserta didik untuk membantu proses pembelajaran.

b. Menguasasi teori belajar dan prinsip pembelajaran yang mendidik.

Guru menetapkan berbagai pendekatan, strategi, metode, dan teknik pembelajaran yang mendidik secara kreatif sesuai dengan standar kompetensi guru.

c. Pengembangan kurikulum.

Guru menyusun silabus sesuai dengan tujuan terpenting kurikulum dan menggunakan RPP sesuai dengan tujuan dan lingkungan pembelajaran.

d. Kegiatan pembelajaran yang mendidik.

Guru menyusun dan melaksanakan rancangan pembelajaran yang mendidik secara lengkap. Guru melaksanakan kegiatan pembelajaran yang sesuai dengan kebutuhan peserta didik. Guru menyusun dan menggunakan berbagai materi pembelajaran dan sumber belajar sesuai dengan karakteristik peserta didik.

e. Pengembangan potensi peserta didik.

Guru menganalisis potensi pembelajaran setiap peserta didik dan mengidentifikasi pengembangan potensi peserta didik melalui program pembelajaran yang mendukung siswa mengaktualisasikan potensi akademik, kepribadian, dan kreativitasnya sampai ada bukti jelas bahwa peserta didik mengaktualisasikan potensi mereka.

f. Komunikasi dengan peserta didik.

Guru berkomunikasi secara efektif, empatik dan santun dengan peserta didik dan bersikap antusias dan positif. Guru memberikan respon yang lengkap dan relevan kepada komentar atau pertanyaan peserta didik. 
g. Penilaian dan evaluasi.

Guru menyelenggarakan penilaian proses dan hasil belajar secara berkesinambungan. Guru melakukan evaluasi atas efektivitas proses dan hasil belajar dan menggunakan informasi hasil penilaian dan evaluasi untuk merancang program remedial dan pengayaan.

h. Bertindak sesuai dengan norma agama, hukum, sosial, dan kebudayaan nasional.

Guru bertindak sesuai dengan hukum di Indonesia. Semua kegiatan yang dilaksanakan oleh guru mengindikasikan penghargaanya terhadap berbagai keberagaman agama, keyakinan yang dianut, suku, adat istiadat daerah asal, latar belakang sosial ekonomi, dan/atau tampilan fisik.

i. Menunjukkan pribadi yang dewasa dan teladan. Guru menampilkan diri sebagai teladan bagi peserta didik dan masyarakat. Guru dihormati oleh peserta didiknya dan oleh anggota masyarakat sekitarnya, termasuk orang tua siswa.

j. Etos kerja, tanggung jawab yang tinggi, rasa bangga menjadi guru.

Guru berperilaku sesuai dengan kode etik profesi guru. Guru melaksanakan tugasnya sesuai dengan harapan kepala sekolah/ madrasah dan komite sekolah/ madrasah. Semua kegiatan guru memperhatikan kebutuhan peserta didik, teman sekerja, dan tujuan sekolah

k. Bersikap inklusif, bertindak obyektif, serta tidak diskriminatif.

Guru menghargai peserta didik, orang tua peserta didik dan teman sejawat. Guru bertindak inklusif, serta tidak diskriminatif terhadap peserta didik, teman sejawat, dan masyarakat sekitar. Guru menerapkan metode pembelajaran yang memfasilitasi pembelajaran semua peserta didik.

1. Komunikasi dengan sesama guru, tenaga kependidikan, orang tua, peserta didik, dan masyarakat.

Guru berkomunikasi secara efektif baik lisan maupun tulisan dengan orang tua peserta didik dan masyarakat. Guru menyediakan informasi resmi (baik lisan maupun tulisan) kepada orang tua peserta didik tentang program pembelajaran dan kemajuan peserta didik (sekurang-kurangnya dua kali dalam setahun). Guru berpartisipasi dalam kegiatan kerjasama antara sekolah dan masyarakat dan berkomunikasi dengan komunitas profesi dan berpartisipasi dalam kegiatan yang relevan.

m. Penguasaan materi, struktur, konsep, dan pola pikir keilmuan yang mendukung mata pelajaran yang diambil.

Merupakan bagian dari kompetensi profesional dimana guru benar-benar memahami mata pelajaran dan bagaimana mata pelajaran tersebut disajikan di dalam kurikulum.

n. Mengembangkan Keprofesionalan melalui tindakan yang reflektif.

Merupakan bagian dari kompetensi profesional dimana guru melakukan refleksi terhadap kinerja sendiri secara terus menerus dan memanfaatkan hasil refleksi untuk meningkatkan keprofesian.

\section{Pengaruh Budaya Organisasi dan \\ Komitmen terhadap Kinerja Guru}

Kinerja guru merupakan suatu peranan yang penting dalam mewujudkan visi dan misi sekolah serta dalam pencapaian tujuan pendidikan. Dan di dalam pelaksanaannya, tidak terlepas dari faktor yang mempengaruhi kinerja itu sendiri antara lain budaya organisasi dan komitmen.

Berbagai penelitian mengenai perilaku organisasi menunjukkan bahwa peran budaya organisasi mendukung efektivitas organisasi dan respon individu. Kecocokan anggota organisasi dengan budaya yang berlaku dapat meningkatkan produktivitas, kepuasan dalam bekerja, kinerja (performance), komitmen organisasi, dan keinginan untuk tetap tinggal di perusahaan. Menurut Sudarmanto (2009:181), budaya organisasi terbentuk dari persepsi subjektif anggota organisasi terhadap nilai-nilai inovasi, toleransi risiko, tekanan pada tim, dan dukungan orang. Persepsi keseluruhan itu akan membentuk budaya atau kepribadian organisasi. Selanjutnya, budaya organisasi akan mempengaruhi kinerja dan kepuasan karyawan, baik mendukung atau tidak mendukung.

Sedangkan pengaruh komitmen terhadap kinerja guru antara lain menurut Sutrisno (2010:306), bagi organisasi apapun, komitmen yang kuat dari para anggota mutlak diperlukan. Adanya komitmen akan meningkatkan kinerja dan mendorong individu aktif terlibat dalam berbagai masalah penting dalam organisasi. Keinginan untuk mengembangkan kompetensi pribadi yang dapat memberikan kontribusi berarti bagi organisasi akan muncul apabila individu punya komitmen yang kuat.

\section{PEMBahasan}

\section{Analisis}

\section{a. Deskriptif Kualitatif}

Analisis deskriptif dimaksudkan untuk mendapatkan gambaran atau deskripsi mengenai tanggapan dari guru mengenai pengaruh budaya organisasi dan komitmen terhadap kinerja guru pada SMK GKP2 2 Pematangsiantar. Setelah pengujian data, maka langkah selanjutnya adalah peneliti melakukan pengkajian analisis kualitatif sebagai gambaran fenomena dari variabel penelitian pada saat sekarang ini. Adapun penetapan kriteria nilai data-data jawaban dari responden tersebut dimasukkan ke dalam kelas-kelas interval, dimana penentuan intervalnya menggunakan rumus sebagai berikut:

Interval kelas $=\frac{\text { Nilail Tertinggi }- \text { Nilai Terendah }}{\text { (jumlah kelas interval) }}$

$$
\begin{aligned}
& =\frac{5-1}{5} \\
& =\frac{4}{5} \\
& =0,8
\end{aligned}
$$


Dari rumus di atas, diperoleh nilai interval kelas $=$ 0,8 , sehingga berlaku ketentuan kategori dengan hasil sebagai berikut:

Tabel 1

Nilai Interval dan Kategori Jawaban Responden.

\begin{tabular}{|c|c|}
\hline $\begin{array}{c}\text { Nilai } \\
\text { Interval }\end{array}$ & Kategori \\
\hline $1,00-1,80$ & $\begin{array}{c}\text { Sangat Kuat (SK) / Sangat Tinggi } \\
\text { (ST) / Sangat Tidak Baik (STB) }\end{array}$ \\
\hline $1,81-2,60$ & $\begin{array}{c}\text { Kuat (K) / Tinggi (T) / Tidak Baik } \\
\text { (TB) }\end{array}$ \\
\hline $2,61-3,40$ & $\begin{array}{c}\text { Sedang (S) / Cukup Tinggi (CT) / } \\
\text { Cukup Baik (CB) }\end{array}$ \\
\hline $3,41-4,20$ & $\begin{array}{c}\text { Lemah (L) / Rendah (R) / Baik (B) } \\
\text { Sangat Lemah (SL) / Sangat } \\
\text { Rendah (SR) Sangat Baik (SB) }\end{array}$ \\
\hline
\end{tabular}

Sumber: data diolah

\section{1) Budaya Organisasi pada SMK GKPS 2 Pematangsiantar}

Penerapan budaya pada organisasi akan membentuk dan menciptakan keteraturan dalam bersikap ataupun bertingkah laku di dalam organisasi. Jika guru menerapkan budaya organisasi di dalam kegiatannya sehari-hari, maka tingkat kepercayaandiri guru terhadap pekerjaannya akan semakin meningkat, dengan begitu guru tersebut akan menghasilkan kinerja yang semakin baik.

Adapun budaya organisasi yang diterapkan oleh SMK GKPS 2 Pematangsiantar ialah jenis 7 budaya malu yaitu malu karena datang terlambat, hal ini bertujuan untuk meningkatkan kedisiplinan serta sikap menghargai waktu oleh para guru, pegawai serta seluruh peserta didik. Malu karena melihat rekan sibuk melakukan aktivitas, hal ini bertujuan untuk menumbuhkan rasa saling membantu dan bekerjasama dalam organisasi. Malu karena melanggar peraturan, hal ini bertujuan untuk meningkatkan kedisiplinan serta sikap menghargai aturan dalam sekolah. Malu untuk berbuat salah, hal ini bertujuan untuk meningkatkan ketelitian bekerja serta konsentrasi belajar para guru, pegawai serta peserta didik.

Malu karena bekerja tidak berprestasi, hal ini bertujuan untuk meningkatkan prestasi belajar dan ketekunan bekerja para guru, pegawai serta para peserta didik. Malu karena tugas tidak terlaksana atau sesuai tidak tepat waktu, menciptakan rasa malu terhadap para guru, pegawai serta peserta didik apabila tugas yang mereka kerjakan tidak terlaksana dengan baik dan tidak selesai dengan tepat waktu. Dan malu karena tidak berperan aktif dalam mewujudkan 7K, menciptakan rasa malu terhadap para guru, pegawai serta siswa/siswi apabila tidak berperan dalam mewujudkan 7K (Keamanan, Kebersihan, Ketertiban, Keindahan, Kekeluargaan, Kesehatan dan Kerindangan).

Berdasarkan hasil analisis deskriptif kualitatif tentang budaya organisasi diperoleh nilai rata-rata sebesar 3,99 dengan kriteria kuat. Nilai rata-rata budaya organisasi tertinggi pada dimensi malu karena tidak berperan aktif dalam mewujudkan $7 \mathrm{~K}$ dengan indikator peran mewujudkan $7 \mathrm{~K}$ dalam lingkungan sekolah, yang berada pada rata-rata 4,13 dengan kriteria kuat. Nilai rata-rata terendah berada pada dimensi malu karena melanggar peraturan, yang berada pada rata-rata 3,36 dengan kriteria sedang.

\section{2) Komitmen pada SMK GKPS 2 \\ Pematangsiantar}

Komitmen adalah suatu keadaan dimana seseorang mau dan yakin untuk tetap tinggal dalam suatu organisasi dan ikut serta dalam melaksanakan tujuan bersama, serta mau mempertahankan keanggotaannya dalam organisasi tersebut. Komitmen sangat berpengaruh terhadap kinerja guru pada SMK GKPS 2 Pematangsiantar. Adapun penerapan komitmen pada SMK GKPS 2 Pematangsiantar antar lain : Komitmen afektif, yaitu keterikatan emosional guru SMK GKPS 2 Pematangsiantar dan keterlibatan dalam organisasi.

Komitmen berkelanjutan, yaitu berhubungan dengan dedikasi guru SMK GKPS 2 Pematangsiantar dalam melangsungkan kehidupan organisasi dan menghasilkan guru-guru yang mau berkorban dan berinvestasi pada organisasi. Serta komitmen normatif, yaitu kewajiban guru SMK GKPS 2 Pematangsiantar untuk bertahan dalam organisasi untuk alasan-alasan moral atau etis.

Berdasarkan hasil analisis deskriptif kualitatif tentang komitmen diperoleh nilai rata-rata sebesar 3,89 dengan kriteria tinggi. Untuk nilai tertinggi yaitu diperoleh nilai rata-rata 4,11 dengan kriteria jawaban tinggi pada dimensi komitmen afektif dengan indikator keterlibatan memecahkan masalah. Sedangkan untuk nilai terendah yaitu diperoleh nilai rata-rata 3,39 dengan kriteria cukup tinggi pada dimensi komitmen afektif dengan indikator perasaan menjadi keluarga sekolah.

\section{3) Kinerja Guru pada SMK GKPS 2 \\ Pematangsiantar}

Kinerja menjadi hal yang penting untuk ditingkatkan oleh seorang guru sehingga tujuan pendidikan dapat tercapai secara efektif dan efisien. Pengukuran kinerja guru bersumber dari kompetensi guru menurut Peraturan Menteri Pendidikan Nasional Nomor 16 Tahun 2007 tentang Standar Kualifikasi Akademik dan Kompetensi Guru dengan 14 dimensi.

Pada dimensi menguasai karakteristik peserta didik, yaitu guru mencatat dan menggunakan informasi tentang karakteristik peserta didik guna membantu proses pembelajaran. Dimensi menguasasi teori belajar dan prinsip pembelajaran yang mendidik, guru menetapkan berbagai pendekatan, strategi, metode, dan teknik pembelajaran yang mendidik secara kreatif sesuai dengan standar kompetensi guru. Dimensi Pengembangan kurikulum, yaitu guru menyusun silabus sesuai dengan tujuan terpenting kurikulum. Dimensi kegiatan pembelajaran yang mendidik, guru menyusun dan melaksanakan rancangan pembelajaran yang mendidik secara lengkap. 
Dimensi pengembangan potensi peserta didik, guru menganalisis potensi pembelajaran setiap peserta didik dan mengidentifikasi pengembangan potensi peserta didik melalui program pembelajaran yang mendukung.

Pada dmensi komunikasi dengan peserta didik, guru berkomunikasi secara efektif, empatik dan santun dengan peserta didik dan bersikap antusias dan positif. Dimensi penilaian dan evaluasi, yaitu guru menyelenggarakan penilaian proses dan hasil belajar secara berkesinambungan. Dimensi bertindak sesuai dengan norma agama, hukum, sosial, dan kebudayaan nasional, yaitu guru bertindak sesuai dengan hukum yang diterapkan di Indonesia. Dimensi menunjukkan pribadi yang dewasa dan teladan, yaitu guru menampilkan diri sebagai teladan bagi peserta didik dan masyarakat. Dimensi etos kerja, tanggung jawab yang tinggi serta rasa bangga menjadi guru, yaitu guru berperilaku sesuai dengan kode etik profesi guru.

Dimensi bersikap inklusif, bertindak obyektif, serta tidak diskriminatif, yaitu guru bertindak inklusif, serta tidak diskriminatif terhadap peserta didik, rekan kerja, dan masyarakat sekitar. Dimensi komunikasi dengan sesama guru, tenaga kependidikan, orang tua, peserta didik, dan masyarakat, yaitu guru berkomunikasi secara efektif baik lisan maupun tulisan dengan orang tua peserta didik dan masyarakat. Dimensi penguasaan materi, struktur, konsep, dan pola pikir keilmuan yang mendukung mata pelajaran yang diambil, merupakan bagian dari kompetensi profesional dimana guru benar-benar memahami mata pelajaran dan bagaimana mata pelajaran tersebut disajikan di dalam kurikulum. Serta dimensi pengembangkan keprofesionalan melalui tindakan yang reflektif, merupakan bagian dari kompetensi profesional dimana guru melakukan refleksi terhadap kinerja sendiri secara terus menerus dan memanfaatkan hasil refleksi untuk meningkatkan keprofesian.

Berdasarkan hasil analisis deskriptif kualitatif tentang kinerja guru diperoleh nilai rata-rata sebesar 3,82 dengan kategori jawaban baik. Untuk nilai tertinggi yaitu diperoleh nilai rata-rata 4,02 dengan kriteria jawaban baik pada dimensi pengembangan potensi peserta didik dengan indikator kemampuan mengidentifikasi potensi peserta didik. Sedangkan untuk nilai terendah yaitu diperoleh nilai rata-rata 3,37 dengan kriteria cukup baik pada dimensi penilaian dan evaluasi dengan pelaksanaan penilaian terhadap peningkatan potensi peserta didik.

\section{b. Deskriptif Kuantitatif}

\section{1) Analisis Regresi Linier Berganda}

Penelitian ini memiliki tujuan untuk menganalisis pengaruh budaya organisasi dan komitmen terhadap kinerja guru. Analisis regresi linier berganda digunakan untuk mengetahui pengaruh variabel bebas $(\mathrm{X})$ dan variabel terikat $(\mathrm{Y})$, dimana X1 adalah budaya organisasi, X2 adalah komitmen dan $\mathrm{Y}$ adalah kinerja guru.
Analisis dijalankan dengan melakukan tabulasi jabawan responden pada kuesioner yang telah dijalankan, sebagai berikut:

Tabel 2

Hasil Regresi Linier Berganda Coefficients $^{a}$

\begin{tabular}{|l|r|r|r|}
\hline \multirow{2}{*}{ Model } & \multicolumn{2}{|c|}{$\begin{array}{c}\text { Unstandardized } \\
\text { Coefficients }\end{array}$} & $\begin{array}{c}\text { Standardize } \\
\boldsymbol{d} \\
\text { Coefficients }\end{array}$ \\
\cline { 2 - 4 } & $\mathbf{1}$ & \multicolumn{1}{|c|}{$\begin{array}{c}\text { Std. } \\
\text { Error }\end{array}$} & \multicolumn{1}{c|}{ Beta } \\
\hline $\begin{array}{l}\text { (Constant) } \\
\text { Budaya } \\
\text { Organisasi }\end{array}$ & $\mathbf{6 8 , 7 1 0}$ & 13,037 &, 447 \\
Komitmen &, $\mathbf{7 1 5}$ &, 218 &, 275 \\
\hline
\end{tabular}

a. Dependent Variable: Kinerja Guru

Sumber : hasil pengolahan data primer

Dari tabel di atas, dapat diperoleh persamaan regresi adalah sebagai berikut: $\hat{\mathrm{Y}}=68,710+0,715 \mathrm{X}_{1}$ $+0,914 \mathrm{X}_{2}$, artinya terdapat pengaruh yang positif antara budaya organisasi dan komitmen terhadap kinerja guru SMK GKPS 2 Pematangsiantar.

\section{2) Analisis Koefisien Korelasi dan Koefisien Determinan (KD)}

Untuk menghitung kekuatan hubungan budaya organisasi dan komitmen terhadap kinerja guru dilakukan analisis korelasi, berupa derajat atau kedalaman hubungan fungsional yang menjelaskan hubungan antara perubah, dinyatakan dengan koefisien korelasi yang disimbolkan dengan r. Nilai $r$ dapat dilihat melalui tabel berikut:

Tabel 3

Hasil Koefisien Korelasi dan Koefisien Determinasi

Model Summary

\begin{tabular}{|c|c|c|r|c|}
\hline Model & $\mathbf{r}$ & $\begin{array}{c}\text { Rodel Summary } \\
\text { Square }\end{array}$ & $\begin{array}{c}\text { Adjusted } \\
\text { R Square }\end{array}$ & $\begin{array}{c}\text { Std. Error } \\
\text { of the } \\
\text { Estimate }\end{array}$ \\
\hline 1 & $\mathbf{6 7 2}^{\mathrm{a}}$ &, $\mathbf{4 5 2}$ &, 434 & 9,742 \\
\hline
\end{tabular}

a. Predictors: (Constant), Variabel X (Budaya

Organisasi Dan Komitmen )

b. Dependent Variable: Variabel Y (Kinerja Guru) Sumber : hasil pengolahan data

Dari tabel 3, didapat $r=0,672$ yang artinya terdapat hubungan yang kuat dan positif antara budaya organisasi dan komitmen dengan kinerja guru pada SMK GKPS 2 Pematangsiantar. Selanjutnya diperoleh koefisien determinasi $\mathrm{R}$ square 0,452 artinya baik tidaknya kinerja guru dapat dijelaskan sebesar $45,2 \%$ oleh budaya organisasi dan komitmen, selebihnya 54,8\% dijelaskan oleh faktor-faktor lain seperti komunikasi, pelatihan, lingkungan kerja, dan faktor-faktor lain yang tidak dibahas dalam penelitian ini.

\section{3) Uji Hipotesis}

a) Uji Simultan (Uji F) 
Uji $\mathrm{F}$ digunakan untuk mengetahui apakah variabel bebas (budaya organisasi dan komitmen) berpengaruh terhadap variabel terikat (kinerja guru) secara bersama-sama atau simultan. Pengujian ini dilakukan untuk membandingkan antara $F_{\text {hitung dan }}$ $F_{\text {tabel }}$ pada taraf signifikansi sebesar 5\% atau $\alpha=0,05$ dengan menggunakan program aplikasi SPSS, dapat dilihat dari tabel berikut:

\section{Tabel 4}

Perkiraan Nilai Fhitung

ANOVA $^{\mathrm{a}}$

\begin{tabular}{|c|r|r|r|r|r|}
\hline Model & $\begin{array}{r}\text { Sum of } \\
\text { Squares }\end{array}$ & $\begin{array}{r}\text { D } \\
\text { f }\end{array}$ & $\begin{array}{c}\text { Mean } \\
\text { Square }\end{array}$ & F & Sig. \\
\hline Regression & 4777,94 & 2 & 2388,974 & $\mathbf{2 5 , 1 7}$ & $\mathbf{0 0 0}$ \\
8 & & & $\mathbf{0}$ & $\mathbf{b}$ \\
1 Residual & 5789,80 & 61 & 94,915 & & \\
2 & & & & \\
Total & 10567,75 & 63 & & & \\
& & & & & \\
\hline
\end{tabular}

a. Dependent Variable: Kinerja Guru (Y)

b. Predictors: (Constant), Budaya Organisasi (X1), Komitmen (X2)

Sumber : hasil pengolahan data primer

Berdasarkan tabel 4 , diperoleh nilai $F_{\text {hitung }}$ sebesar 25,170 $>F_{\text {tabel }}(0,05 ; 2$ VS 61) sebesar 3,15 atau dengan taraf signifikan $0,000<\alpha 0,05$, maka $\mathrm{H}_{0}$ ditolak, artinya budaya organisasi dan komitmen berpengaruh positif dan signifikan terhadap kinerja guru SMK GKPS 2 Pematangsiantar.

\section{b) Uji Parsial (Uji t)}

Untuk menghasilkan suatu kesimpulan yang valid, maka harus dilakukan uji hipotesis (uji t). Dari hasil perhitungan koefisien korelasi diketahui bahwa budaya organisasi, komitmen, dan kinerja guru sangat berhubungan, untuk menguji kebenarannya maka dilakukan pengujian hipotesis dengan menggunakan program SPSS, dapat dilihat pada tabel berikut ini:

Tabel 5

Perkiraan Nilai thitung

Coefficients $^{\mathrm{a}}$

\begin{tabular}{|l|r|r|}
\hline \multicolumn{3}{|c|}{ Coefficients $^{\mathrm{a}}$} \\
\hline Model & $\mathbf{t}$ & \multicolumn{1}{c|}{ Sig. } \\
\hline (Constant) & $\mathbf{5 , 2 7 0}$ & $\mathbf{, 0 0 0}$ \\
Budaya Organisasi (X1) & $\mathbf{3 , 2 7 4}$ & $\mathbf{, 0 0 2}$ \\
Komitmen (X2) & $\mathbf{2 , 0 1 5}$ &, $\mathbf{0 4 8}$ \\
\hline
\end{tabular}

a. Dependent Variable: Kinerja Guru

Sumber : hasil pengolahan data primer

Dari tabel 5, dapat dilihat nilai thitung pada variabel $\mathrm{X}_{1}$ (budaya organisasi) sebesar 3,274 $>\mathrm{t}_{\text {tabel }}$ dengan df $=\mathrm{n}-\mathrm{k}-1 \quad(64-2-1=61)$ sebesar 1,99962, atau dengan taraf signifikan $0,002<\alpha 0,05$, maka $\mathrm{H}_{0}$ ditolak, artinya budaya organisasi berpengaruh positif dan signifikan terhadap guru SMK GKPS 2 Pematangsiantar.

Sedangkan $t_{\text {hitung }}$ pada variabel $\mathrm{X}_{2}$ (komitmen) sebesar 2,015 $>\mathrm{t}_{\text {tabel }}$ dengan $\mathrm{df}=\mathrm{n}-\mathrm{k}-1 \quad(64-2-1=61)$ sebesar 1,99962, atau dengan taraf signifikan 0,048 $<\alpha 0,05$, maka $\mathrm{H}_{0}$ ditolak, artinya komitmen berpengaruh positif dan signifikan terhadap kinerja guru SMK GKPS 2 Pematangsiantar.

\section{Evaluasi}

a. Budaya Organisasi pada SMK GKPS 2 Pematangsiantar

Budaya organisasi SMK GKPS 2 Pematangsiantar dapat dikatakan kuat. Hal tersebut dibuktikan berdasarkan kuesioner yang dibagikan penulis, dan diperoleh nilai rata-rata jawaban sebesar 3,99 dengan kriteria jawaban kuat.

Walaupun sudah dikatakan kuat, masih ada indikator yang dibawah rata-rata yaitu pada dimensi malu karena datang terlambat dengan indikator menghargai waktu bekerja berada pada nilai rata-rata 3,37 dengan kriteria jawaban cukup tinggi, untuk mengatasinya maka sebaiknya diperlukan adanya pengawasan yang lebih serta sanksi yang lebih berat dari kepala sekolah bagi para guru yang melanggar peraturan.

Dimensi malu karena melanggar peraturan pada indikator menghargai aturan yang berlaku dengan nilai rata-rata 3,36 berkriteria jawaban cukup tinggi, untuk mengatasi hal ini sebaiknya kepala sekolah memberikan arahan kepada para guru untuk lebih menghargai serta menaati peraturan yang berlaku di sekolah. Pada dimensi malu karena tugas tidak terlaksana atau sesuai tidak tepat waktu dengan indikator ketepatan waktu menyelesaikan pekerjaan dengan nilai rata-rata 3,95 dengan kriteria jawaban tinggi, untuk mengatasinya sebaiknya kepala sekolah memberikan pengawasan yang lebih ketat terhadap pekerjaan maupun hasil kerja guru-guru.

\section{b. Komitmen pada SMK GKPS 2 \\ Pematangsiantar}

Komitmen pada SMK GKPS 2 Pematangsiantar dapat dikategorikan sudah tinggi, hal ini dapat dilihat dari hasil kuesioner yang dibagikan kepada responden yang secara keseluruhan diperoleh nilai rata-rata 3,89 dengan kriteria jawaban tinggi.

Namun masih ada beberapa indikator yang dibawah rata-rata dan masih perlu ditingkatkan seperti pada dimensi komitmen afektif pada indikator keterlibatan memecahkan masalah berada pada ratarata 3,39 dengan kriteria jawaban baik. Cara meningkatkan indikator ini yaitu dengan adanya pendekatan dari kepala sekolah terhadap guru-guru yang jarang memberikan pendapatnya terhadap pemecahan masalah sekolah.

Pada dimensi komitmen berkelanjutan di indikator kerugian yang dirasakan jika meninggalkan sekolah berada pada rata-rata 3,87 dengan kriteria jawaban baik. Cara meningkatkannya yaitu kepala sekolah sebaiknya selalu berusaha lebih dekat serta lebih santai dengan para guru sehingga guru tidak merasa sungkan dalam menyampaikan pendapat atau ketidaksenangannya, sehingga rasa rugi yang dirasakan guru apabila meninggalkan sekolah serta keterikatan guru dengan sekolah semakin meningkat. 
Dan pada indikator kepentingan yang dirasakan jika tetap bertahan dalam sekolah berada pada rata-rata 3,86 dengan kriteria jawaban baik. Cara meningkatkannya yaitu dengan meningkatkan kekerabatan serta nilai persaudaraan antar sesama guru, lebih menghargai serta menhormati sesama rekan guru.

\section{c. Kinerja Guru pada SMK GKPS 2 \\ Pematangsiantar \\ Kinerja guru pada SMK GKPS 2}

Pematangsiantar dapat dikatakan baik, hal ini dapat dilihat dari nilai rata-rata yang di dapat dari pengisian kuesioner mengenai kinerja pegawai yang dibagikan memperoleh nilai rata-rata 3,82 dengan kriteria jawaban baik.

Namun masih ada indikator-indikator yang perlu di tingkatkan dengan nilai dibawah rata-rata seperti yang terdapat pada dimensi menguasai karakteristik peserta didik dengan indikator kemampuan mengidentifikasi karakteristik peserta didik berada pada rata-rata 3,39 dengan kriteria jawaban baik. Cara meningkatkannya yaitu sebaiknya guru-guru lebih melakukan pendekatan kembali dengan para peserta didik. Pada indikator pengembangan kurikulum dengan indikator menyesuaikan penyusunan silabus pembelajaran dengan kurikulum berada pada rata-rata 3,81 dengan kriteria jawaban baik, cara meningkatkannya yaitu adanya pengarahan kepala sekolah agar para guru menyesuaikan penyusunan silabus pembelajarannya dengan kurikulum yang digunakan sekolah saat itu. Pada indikator menyesuaikan pembelajaran dengan silabus berada rata-rata 3,39 dengan kriteria jawaban cukup baik, cara meningkatkannya yaitu kepala sekolah memberikan tugas kepada para guru untuk membuat catatan konsep pembelajarannya.

Pada dimensi kegiatan pembelajaran yang mendidik dengan indikator kemampuan menggunakan alat bantu dalam mengajar berada pada rata-rata 3,75 dengan kriteria jawaban baik, cara meningkatkannya yaitu adanya arahan dari kepala sekolah dalam penggunaan alat bantu dalam mengajar. Pada dimensi penilaian dan evaluasi dengan indikator pelaksanaan penilaian terhadap peningkatan potensi peserta didik berada pada ratarata 3,37 dengan kriteria jawaban cukup baik. cara meningkatkannya yaitu sebaiknya kepala sekolah memberikan tugas kepada para guru untuk membuat catatan tentang perkembangan peserta didik. Pada indikator ketepatan waktu pelaksanaan proses pembelajaran berada pada nilai rata-rata 3,39 dengan kriteria cukup baik, cara meningkatkannya yaitu memberikan sanksi terhadap guru-guru yang meninggalkan kelas sebelum bel pulang. Pada indikator ketepatan waktu menyelesaikan tugas administratif berada pada rata-rata 3,84 dengan kriteria jawaban baik, cara meningkatkannya yaitu sebaiknya kepala sekolah lebih melakukan pengawasan dan arahan terhadap tugas-tugas guru.

Pada dimensi bersikap inklusif, bertindak obyektif, serta tidak diskriminatif dengan indikator keadilan memberikan penilaian terhadap peserta didik berada pada rata-rata 3,80 dengan kriteria jawaban baik, cara meningkatkannya yaitu sebaiknya guru aktif melakukan kuis untuk nilai tambahan pada saat proses pembelajaran. Pada indikator rasa toleransi terhadap kesalahan rekan kerja berada pada rata-rata 3,66 dengan kriteria jawaban baik, cara meningkatkannya yaitu sebaiknya para guru lebih sering melakukan perbincangan diluar masalah sekolah serta diluar lingkungan sekolah. Pada dimensi komunikasi dengan sesama guru, tenaga kependidikan, orangtua peserta didik, dan masyarakat dengan indikator keaktifan berkomunikasi dengan rekan kerja didik berada pada rata-rata 3,73 dengan kriteria jawaban baik, cara meningkatkannya sebaiknya guru-guru lebih melakukan komunikasi sebelum mereka pulang dari sekolah. Pada indikator keaktifan berkomunikasi dengan masyarakat berada pada rata-rata 3,70 dengan kriteria jawaban baik, cara meningkatkannya sebaiknya guru-guru berkomunikasi dengan masyarakat sekitar dengan lebih aktif lagi.

Pada dimensi penguasaan materi, struktur, konsep, dan pola pikir keilmuan yang mendukung mata pelajaran dengan indikator memetakan standar kompetensi materi pembelajaran berada pada ratarata 3,80 dengan kriteria jawaban baik, cara meningkatkannya yaitu melakukan pengarahan lebih kepada guru tentang standar kompetensi materi pembelajaran. Pada indikator strategi mengalokasikan waktu proses pembelajaran berada pada rata-rata 3,72 dengan kriteria jawaban baik, cara meningkatkannya yaitu sebaiknya guru-guru mengalokasikan waktu proses pembelajaran sesuai dengan kebutuhan peserta didik. Pada dimensi mengembangkan keprofesionalan melalui tindakan yang reflektif dengan indikator keaktifan dalam mengembangkan keprofesionalan berada pada ratarata 3,72 dengan kriteria jawaban baik, cara meningkatkannya yaitu adanya pendekatan dan pengarahan dari kepala sekolah agar guru mau berperan aktif dalam mengembangkan keprofesionalan guna untuk kemajuan sekolah.

Pada indikator memanfaatkan teknologi untuk mendukung pengembangan profesionalitas berada pada rata-rata 3,38 dengan kriteria jawaban baik, cara meningkatkannya yaitu sebaiknya guru-guru lebih menyadari lagi penggunaan teknologi dapat mengifesiensi dalam penyelesaian tugas.

\section{KESIMPULAN DAN SARAN}

\section{Kesimpulan}

a. Hasil analisis deskriptif kualitatif tentang budaya organisasi diperoleh nilai rata-rata jawaban keseluruhan 3,99 dengan kriteria jawaban kuat. Kemudian nilai rata-rata tertinggi sebesar 4,13 pada dimensi malu karena tidak berperan aktif dalam mewujudkan $7 \mathrm{~K}$ dengan indikator peran mewujudkan $7 \mathrm{~K}$ dalam lingkungan sekolah. Selanjutnya nilai terendah sebesar 3,36 pada dimensi malu karena datang terlambat dengan indikator menghargai waktu bekerja.

b. Hasil analisis deskriptif kualitatif tentang komitmen diperoleh nilai rata-rata jawaban 
keseluruhan 3,89 dengan kriteria jawaban tinggi. Untuk nilai rata-rata tertinggi sebesar 4,11 pada dimensi komitmen afektif dengan indikator keterlibatan memecahkan masalah. Sedangkan untuk nilai terendah yaitu diperoleh nilai rata-rata 3,39 pada dimensi komitmen afektif dengan indikator keterlibatan memecahkan masalah dalam sekolah.

c. Hasil analisis deskriptif kualitatif tentang kinerja guru diperoleh nilai rata-rata jawaban keseluruhan 3,82 dengan kriteria jawaban baik. Kemudian nilai rata-rata tertinggi sebesar 4,02 pada dimensi pengembangan potensi peserta didik di indikator kemampuan mengidentifikasi potensi peserta didik. Dan nilai rata-rata terendah sebesar 3,37 pada dimensi penilaian dan evaluasi di indikator pelaksanaan penilaian peningkatan potensi peserta didik

d. Hasil analisis regresi linear berganda dengan menggunakan program SPSS Satistics versi 21 diperoleh nilai $\hat{\mathrm{Y}}=68,710+0,715 \mathrm{X}_{1}+0,914 \mathrm{X}_{2}$, artinya terdapat pengaruh yang positif antara variabel budaya organisasi dan variabel komitmen terhadap kinerja guru pada SMK GKPS 2 Pematangsiantar.

e. Hasil analisis korelasi diperoleh nilai $\mathrm{r}$ sebesar 0,672 yang artinya terdapat hubungan yang kuat dan positif antara budaya organisasi dan komitmen terhadap kinerja guru pada SMK GKPS 2 Pematangsiantar. Kemudian diperoleh nilai koefisian determinasi ( $\mathrm{R}$ square) sebesar 0,452 artinya baik tidaknya kinerja guru (Y) pada SMK GKPS 2 Pematangsiantar sebesar 45,2\% dapat dijelaskan oleh budaya organisasi dan komitmen, sedangkan sisanya sebesar 54,8\% dipengaruhi oleh faktor-faktor lain seperti komunikasi, pelatihan, lingkungan kerja, dan faktor-faktor lain yang tidak dibahas dalam penelitian ini.

f. Hasil pengujian hipotesis secara simultan dengan uji $\mathrm{F}$ sebesar $25,170>\mathrm{F}_{\text {tabel }}(0,05 ; 2 \mathrm{VS} 61)$ sebesar 3,15 atau dengan taraf signifikan 0,000 < $\alpha$ 0,05, maka $\mathrm{H}_{0}$ ditolak, artinya budaya organisasi dan komitmen berpengaruh positif dan signifikan terhadap kinerja guru SMK GKPS 2 Pematangsiantar secara simultan.

g. Hasil pengujian hipotesis secara parsial dengan uji t, terdapat pengaruh yang positif dan signifikan antara budaya organisasi dan komitmen terhadap kinerja guru, diperoleh nilai $t_{\text {hitung pada }} X_{1}$ (budaya organisasi) sebesar 3,274 dengan $(64-2-1=61)$ sebesar 1,99962, atau dengan taraf signifikan $0,002<\alpha 0,05$, maka $\mathrm{H}_{0}$ ditolak, artinya budaya organisasi berpengaruh positif dan signifikan terhadap kinerja guru pada SMK GKPS 2 Pematangsiantar. Sedangkan nilai $t_{\text {hitung pada }} \mathrm{X}_{2}$ (komitmen) sebesar 2,015 dengan $\mathrm{df}=\mathrm{n}-\mathrm{k}-1 \quad(64-2-1=61)$ sebesar 1,99962 atau dengan taraf signifikan $0,048<\alpha 0,05$ maka $\mathrm{H}_{0}$ ditolak, artinya budaya organisasi berpengaruh positif dan signifikan terhadap kinerja guru pada SMK GKPS 2 Pematangsiantar.

\section{Saran}

a. Agar penerapan budaya organisasi semakin kuat, maka sebaiknya kepala sekolah memberikan sanksi ataupun teguran keras kepada guru-guru yang melanggar peraturan, baik guru yang datang terlambat maupun guru yang meninggalkan sekolah sebelum jam pulang.

b. Agar komitmen semakin tinggi, maka sebaiknya kepala sekolah lebih mendekatkan diri kepada guru-guru yang jarang memberikan pendapatnya terhadap pemecahan masalah sekolah. Berusaha lebih dekat serta lebih santai dengan para guru sehingga guru-guru tidak merasa sungkan dalam menyampaikan pendapat.

c. Agar kinerja guru semakin meningkat dengan baik, maka sebaiknya guru-guru lebih melakukan pendekatan kembali dengan para peserta didik serta guru-guru sebaiknya tidak memberikan penilaian kepada peserta didik melalui hasil nilai ujiannya saja.

d. Sehubungan dengan keterbatasan-keterbatasan yang ada pada penulis, penelitian ini masih terdapat kelemahan-kelemahan dan belum dapat mengungkap seluruh variabel yang dapat mempengaruhi kinerja guru pada SMK GKPS 2 Pematangsiantar. Sebagai bahan masukan untuk peneliti selanjutnya, perlu memperbanyak variabel penelitian seperti komunikasi, kompetensi, kemampuan intelektual, disiplin kerja, fasilitas kerja, dan lain-lain.

\section{E. DAFTAR PUSTAKA}

Bangun, Wilson. 2012. Manajemen Sumber Daya Manusia. Jakarta: Erlangga.

Daft, Richard, L. 2002. Manajemen. Jilid 1. Jakarta: Erlangga.

Griffin, Ricky, W. 2004. Manajemen. Edisi Ketujuh. Jilid Satu. Jakarta: Erlangga.

Kreitner, Robert dan Angelo Kinicki. 2015. Perilaku Organisasi. Edisi 9. Buku 1. Jakarta: Salemba Empat.

Mangkunegara, Anwar Prabu. 2017. Manajemen Sumber Daya Manusia Perusahaan. Cetakan Keduabelas. Bandung: Remaja Rosdakarya.

Mathis, Robert L. dan John, H. Jackson. 2006. Human Resourch Management. Edisi 10. Jakarta: Salemba Empat

Mondy, R. Wayne. 2008. Manajemen Sumber Daya Manusia. Jilid 2, Edisi Kesepuluh. Jakarta: Erlangga.

Peraturan Menteri Pendidikan Nasional Nomor 16 Tahun 2007. Tentang Standar Kualifikasi Akademik dan Kompetensi Guru.

Robbins, Stephen P. 2002. Prinsip-Prinsip Perilaku Organisasi. Edisi Kelima. Jakarta: Erlangga.

Robbins, Stephen P. 2007. Perilaku Organisasi. Edisi Kesembilan. Jakarta: Salemba Empat.

Robbins, Stephen P. dan Mary, Coulter. 2011. Manajemen. Edisi Kesepuluh. Jakarta: Erlangga. 
Robbins, Stephen P. dan Timothy A. Judge. 2008. Perilaku Organisasi. Edisi Keduabelas. Jakarta: Salemba Empat.
Sudarmanto. 2009. Kinerja Dan Pembangunan Kompetensi SDM Cetakan Pertama.

Yogyakarta: Pustaka Pelajar.

Sutrisno, Edy. 2010. Budaya Organisasi. Jakarta: Kencana. 